\title{
Chemistry of Mercury Species and Their Control in Coal Combustion
}

\author{
Semi-Annual Report \\ September 1, 1997 - February 28, 1998
}

Work Performed Under Contract No.: DE-FG22-95PC95222

\author{
For \\ U.S. Department of Energy \\ Office of Fossil Energy \\ Federal Energy Technology Center \\ P.O. Box 880 \\ Morgantown, West Virginia 26507-0880
}

By

Aerosol and Air Quality Research Laboratory

Department of Civil and Environment Engineering

University of Cincinnati

Cincinnati, Ohio 


\section{Disclaimer}

This report was prepared as an account of work sponsored by an agency of the United States Government. Neither the United States Government nor any agency thereof, nor any of their employees, makes any warranty, express or implied, or assumes any legal liability or responsibility for the accuracy, completeness, or usefulness of any information, apparatus, product, or process disclosed, or represents that its use would not infringe privately owned rights. Reference herein to any specific commercial product, process, or service by trade

name, trademark, manufacturer, or otherwise does not necessarily constitute or imply its endorsement, recommendation, or favoring by the United States Government or any agency thereof. The views and opinions of authors expressed herein do not necessarily state or reflect those of the United States Government or any agency thereof. 


\section{CHEMISTRY OF MERCURY SPECIES AND THEIR CONTROL IN COAL COMBUSTION}

DOE Grant Agreement No. DE-FG22-95PC95222--07

Aerosol and Air Quality Research Laboratory

Department of Civil and Environment Engineering

University of Cincinnati

Reporting Period: September 1997 - February 1998

Date of Report: February 28, 1998

Grant Date: August 1, 1995

Anticipated Completion Date: July 31, 1998

Program Manager: Diane Revay Madden

Principal Investigator: Pratim Biswas

Contracting Officer's Representative: Cynthia Weitlauf 


\section{OBJECTIVES}

The objectives for this reporting period are:

1) The study of characteristics of sorbent agglomerate generated for $\mathrm{Hg}$ capture

2) The study of particle formation mechanisms of submicron particles generated form pulverized coal combustion.

\section{SUMMARY OF TECHNICAL PROGRESS}

\section{Structural Studies of the $\mathrm{SiO}_{2}$ Agglomerates}

Silica aggregates produced in a tubular aerosol reactor were classified according to the electrical mobility equivalent radius $\left(\mathrm{R}_{\mathrm{E}}\right)$ by differential mobility analyzer (DMA). Then the classified aerosol was further analyzed by 1) in situ light scattering measurement, 2) TEM micrograph analysis to evaluate the properties of agglomerates, such as the radius of gyration $\left(\mathrm{R}_{\mathrm{g}}\right)$, fractal dimension $\left(\mathrm{D}_{\mathrm{f}}\right)$, primary particle diameter $\left(\mathrm{d}_{\mathrm{m}}\right)$ and number of primary particles $(\mathrm{N})$. Based on the properties measured by the experiments, the actual surface area of the silica sorbent particles can be calculated.

The schematic diagram of the system is shown in Figure 1. Two sets of experiments were performed. In set 1, the wave length of the laser light was set at $488 \mathrm{~nm}$ and in set 2, it was set at $514 \mathrm{~nm}$. The conditions for the $\mathrm{SiO}_{2}$ agglomerates generation were 1) furnace temperature of $1000^{\circ} \mathrm{C}, 2$ ) silica precursor feed rate of $25 \mathrm{cc} / \mathrm{min}$, and 3) silica precursor feed temperature of $20^{\circ} \mathrm{C}$. The DMA rod voltages were set at $1.7739 \mathrm{~V}, 2.4524 \mathrm{~V}, 3.3403$ $\mathrm{V}, 4.7072 \mathrm{~V}, 5.9521 \mathrm{~V}$, which classified the $\mathrm{SiO}_{2}$ agglomerates according to the electrical mobility equivalent diameters of $184 \mathrm{~nm}, 228 \mathrm{~nm}, 283 \mathrm{~nm}, 365 \mathrm{~nm}, 437 \mathrm{~nm}$, respectively. The measured signal $\mathrm{S}$ in arbitrary unit vs. wave factor $\mathrm{q}$ are plotted in Figure 2 and 3.

\section{Hg Capture in Presence of Simulated Flue GasCoal Combustion Experiment}

Experiments were conducted in simulated flue gas environments to determine $\mathrm{Hg}$ capture. The details are provided in Appendix I.

\section{Coal Combustion Experiment}


To study the submicrometer particle distribution from pulverized coal combustion, a laboratory scale drop-tube reactor was set up. The schematic diagram of the system is shown in Figure 4. The present experiment system allows for combustion of very small amounts of coal under well-controlled condition. The emphasis in this work has been on the ultra-fine particle formation mechanism in the flue gas. The pulverized coal powders (around $40-60 \mu \mathrm{m}$ ) flow into the vertical tubular reactor. Combustion products then pass through a MARK- $\amalg$ cascade impactor (last stage cutoff diameter $=0.46 \mu \mathrm{m}$ ) to separate the large particle from the flue gas. The CPC (Condensed Particle Counter) was used to measure the total number concentration of ultra-fine particles (in the range between $30 \mathrm{~nm}$ and $800 \mathrm{~nm}$ ), and DMA (Differential Mobility Analyzer) was used for the measurement of particle size distribution. A filter assembly was also installed after the impactor to capture all the submicron particles smaller than $0.5 \mu \mathrm{m}$ for chemical analysis.

The effects of reactor temperature and residence time of coal particle on the particle characteristics were examined by means of changing the reactor temperature and air flow rate through the reactor. Total number concentrations of submicron particles (smaller than $0.5 \mu \mathrm{m})$, and the particle size distributions, were measured under different working condition. The results are plotted in Figure 5 and 6 . It can be found that the shorter the residence time of coal particles in the reactor, the lower the total number concentrations. It is also noted that, with the increase of temperature, the total number concentration first significantly increased. Then, after reaching certain temperature, the total number concentration reduced a little. Particle size distributions under different temperature are shown in Figure 7. Peak value could be observed around $100 \mathrm{~nm}$ particle diameter. It is found that with the rise of temperature, the peak value shifts to the smaller particle size.

\section{PUBLICATIONS}

1) Yang G. and Biswas P.: "Study of the Sintering of Nanosized Titania Agglomerates in Flames Using In Situ Light Scattering Measurements", Aerosol Science and Technology, vol. 27(4), 507-521, 1997.

2) Wu C.Y. and Biswas P.: "Particle Growth by Condensation in a System withLimited Vapor", Aerosol Science and Technology, vol. 28(1), 1-20, 1998.

3) Biswas P. and Wu C.Y.: "Control of Toxic Metal Emissions from Combustors Using Sorbents: A Review", J. Air and Waste Management Associn., vol 48, 113-127, 1998. 
4) C.Y.Wu, T.G.Lee, E.Arar, G.Tyree, P.Biswas, "Capture of Hg from Combustion System By In-Situ Generated Titania Particle with UV-Irradiation", to appear, Combustion Science \& Technology, 1998. 
WORK TO BE PERFORMED OVER NEXT REPORTING PERIOD

During the next period, the following experiments will be performed:

1) Results of mercury capture with other sorbent will be reported. In addition, a detailed kinetic examination of $\mathrm{TiO}_{2}-\mathrm{Hg}$ complexation is being carried out.

2) Effective capture of the toxic species on combustion of coal in electrical fields will be discussed. 


\title{
Appendix I
}

\section{KINETICS OF MERCURY CAPTURE USING TITANIA SORBENTS}

\author{
T.G. LEE and P. BISWAS \\ Aerosol and Air Quality Research Laboratory \\ Environmental Engineering and Science Division; University of Cincinnati \\ Cincinnati, OH 45221-0071
}

\section{KEYWORDS}

Air toxics, Metals, Sorbent capture, Photocatalyst

A novel sorbent methodology wherein a vapor phase sorbent precursor is injected into the combustor has been developed for control of toxic metals emissions from high temperature environments (Owens and Biswas, 1996). This methodology was further developed using in situ generated titania sorbents with uv irradiation for the effective capture of mercury from high temperature gas streams (Biswas and $\mathrm{Wu}, 1998$; Wu et al., 1998). In this work, we examine the kinetics of mercury capture using titania sorbents in simulated combustion environments.

A schematic diagram of the flow reactor with its associated components is shown in Figure 1. Mercury vapors are introduced in precisely controlled amounts using a temperature controlled impinger, titanium isopropoxide vapors are introduced by bubbling argon through a solution of the precursor, and a combustion exhaust was simulated by adding varying amounts of sulfur dioxide. The photochemical reaction cell at the exit of the reactor tube is used to photocatalyze the mercury - titania reactions for better binding of the mercury to the sorbent particle surface. An on line $\mathrm{Hg}$ analyzer (Shimadzu, uv absorption spectrophotometer, $253.7 \mathrm{~nm}$ absorption) was used to monitor the elemental $\mathrm{Hg}$ concentration in the gas phase as indicated in Figure 1.

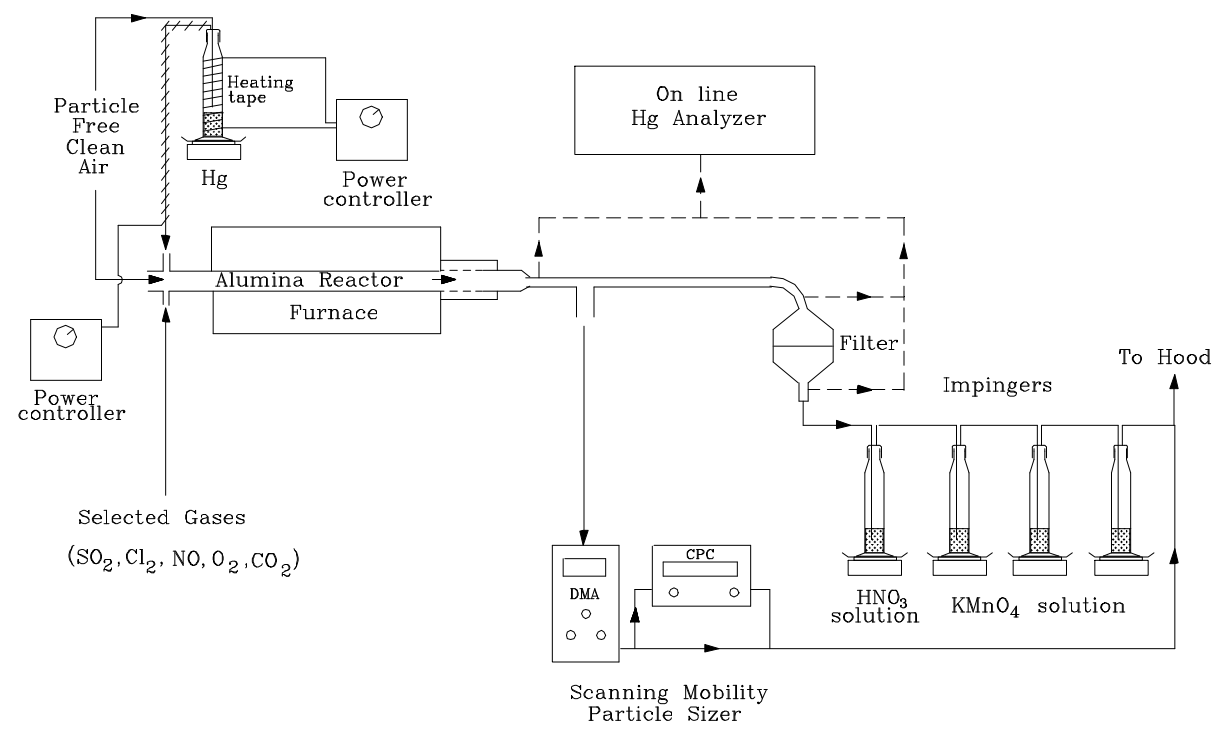

Figure 1. Schematic diagram of experimental system for $\mathrm{Hg}$ capture experiments. 
Previous tests (Wu et al., 1998) illustrated capture efficiencies of mercury as high as 98.6\%. The capture efficiency is defined as the mass of $\mathrm{Hg}$ on the filter (Figure 1) to the total mass of mercury on the filter and impingers (gas phase). Initial tests were carried out to determine the effectiveness of the titania particles to capture mercury in a simulated flue gas environment. On addition of increasing amounts of sulfur dioxide, the capture efficiency drops (Table 1), probably due to the occupation of some of the active sites on the titania particles. On increasing the feed rate of the titanium precursor, and thus the concentration of titania particles (and the available surface area), the efficiency increases to $81.5 \%$ (Table 1), confirming that sulfur dioxide occupies some of the active sites on titania.

Table 1. List of Preliminary Simulation Conditions and Results

\begin{tabular}{|l|c|c|c|c|}
\hline & $\begin{array}{c}\text { Total Flow } \\
\text { Rate } \\
(\mathrm{lpm})\end{array}$ & $\begin{array}{c}\text { Flow Rate of } \mathrm{Ar} \\
\text { through Ti bubbler } \\
(\mathrm{lpm}) / \mathrm{TiO} \text { conc. }(\# / c c)\end{array}$ & $\begin{array}{c}\mathrm{SO}_{2} \\
\text { Conc. } \\
(\mathrm{ppm})\end{array}$ & $\begin{array}{c}\eta \\
(\%)\end{array}$ \\
\hline $\mathrm{Air}+\mathrm{Hg}+\mathrm{Ti}$ & 1.12 & $0.1 /\left(4.40^{*} 10^{7}\right)$ & 0 & 0 \\
\hline $\mathrm{Air}+\mathrm{Hg}+\mathrm{Ti}+\mathrm{UV}$ & 1.12 & $0.1 /\left(4.40^{*} 10^{7}\right)$ & 0 & 98.6 \\
\hline $\mathrm{Air}+\mathrm{Hg}+\mathrm{SO}_{2}+\mathrm{Ti}+\mathrm{UV}-(\mathrm{I})$ & 1.12 & $0.1 /\left(5.28^{*} 10^{7)}\right.$ & 300 & 64.36 \\
\hline $\mathrm{Air}+\mathrm{Hg}+\mathrm{SO}_{2}+\mathrm{Ti}+\mathrm{UV}-(\mathrm{II})$ & 1.12 & $0.1 /\left(5.50^{*} 10^{7}\right)$ & 600 & 55.56 \\
\hline $\mathrm{Air}+\mathrm{Hg}+\mathrm{SO}_{2}+\mathrm{Ti}+\mathrm{UV}-(\mathrm{III})$ & 1.17 & $0.15 /\left(>10^{8}\right)$ & 300 & 81.68 \\
\hline $\mathrm{Air}+\mathrm{Hg}+\mathrm{SO}_{2}+\mathrm{Ti}+\mathrm{UV}-(\mathrm{IV})$ & 1.17 & $0.15 /\left(>10^{8}\right)$ & 600 & 81.48 \\
\hline
\end{tabular}

Furnace Temperature : $1000{ }^{\circ} \mathrm{C}$; Air Flow Rate : $1.0 \mathrm{lpm} ; \mathrm{Hg}$ Inlet Condition : $30{ }^{\circ} \mathrm{C}, 20 \mathrm{cc} / \mathrm{min}$ $\mathrm{Hg}$ Inlet Concentration (measured): $27.22 \sim 28.43 \mu \mathrm{g} / \mathrm{m}^{3}$; Ti Precursor Inlet Temperature : $75^{\circ} \mathrm{C}$

Results of detailed experiments on kinetics of $\mathrm{Hg}$ capture will also be presented. This will be done by examining capture at different residence times in the reactor. In addition, the role of inhibiting the $\mathrm{Hg}$ capture will be firmly established by developing a mechanistic interpretation of the $\mathrm{Hg}$ capture process. Preliminary results indicate that reasonably low ratios of Ti: $\mathrm{Hg}$ can be used in realistic flue gas environments for cost effective capture of $\mathrm{Hg}$.

\section{ACKNOWLEDGMENTS}

This work was partially supported by grants from the US Department of Energy, DE FG2295PC95222 and the Ohio Coal Development Organization, OCRC 97B1.7.

\section{REFERENCES}

Biswas P. and Wu C.Y. (1998)Control of Toxic Metal Emissions from Combustors Using Sorbents: A Review, J. Air and Waste Mgmt. Associn., 113-127.

Owens T.M. and Biswas P. (1996) Vapor Phase Sorbent Precursors for Toxic Metal Emissions Control from Combustors, Ind. Engr. \& Chem. Res., 35, 792-798. 
Wu C.Y., Lee T.G., Tyree G., Arar E. and Biswas P. (1998) Capture of Mercury in Combustion Systems By In Situ Generated Titania Particles with uv Irradiation, to appear, Combust. Sci. \& Technol.. 


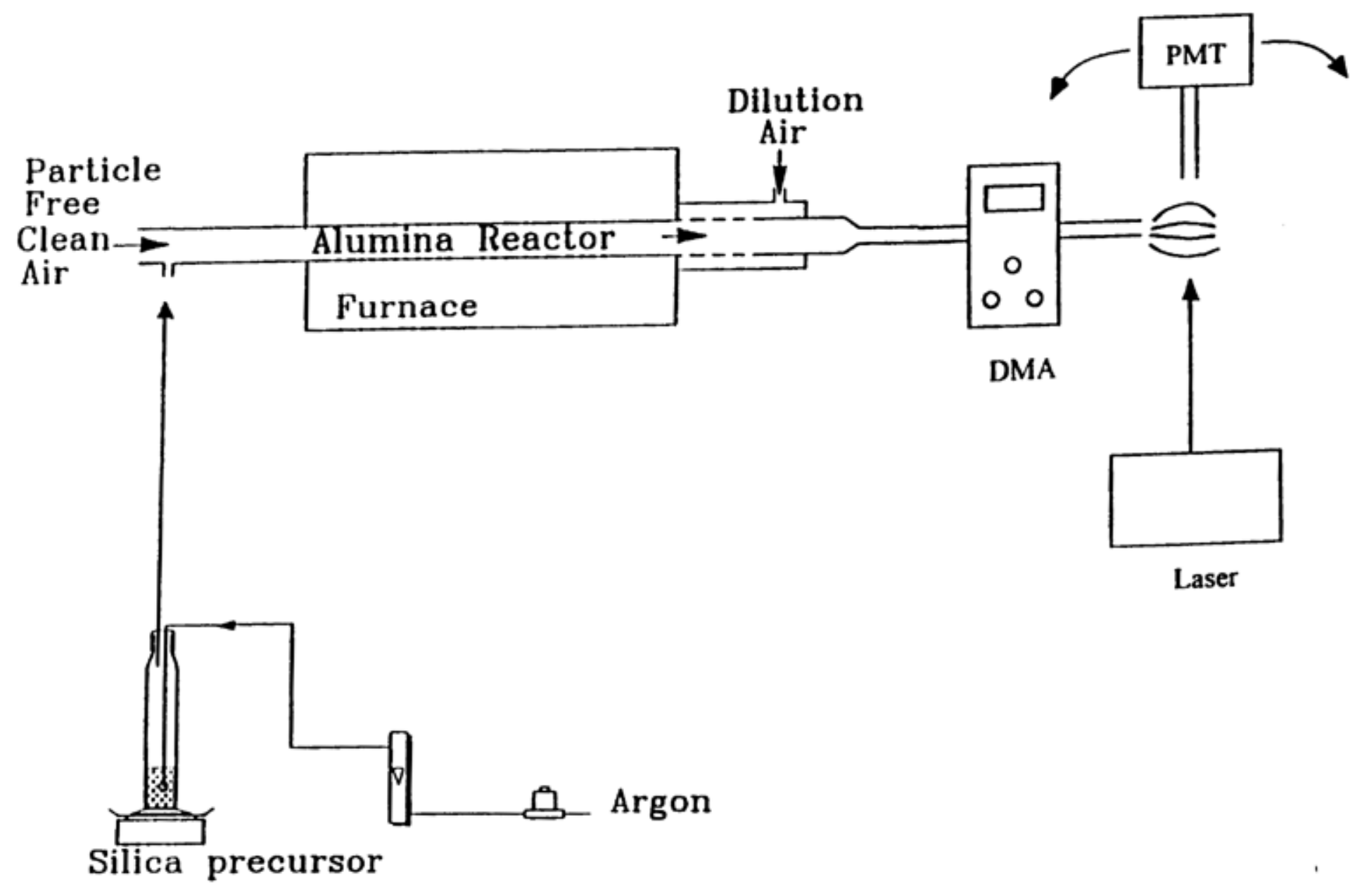

Figure 1 The schematic of the modified system for the structural studies of the agglomerates. 
Figure 2 Measured signal (S) vs. wave factor (q)

Signal Inversion: wave length $=514 \mathrm{~nm}$

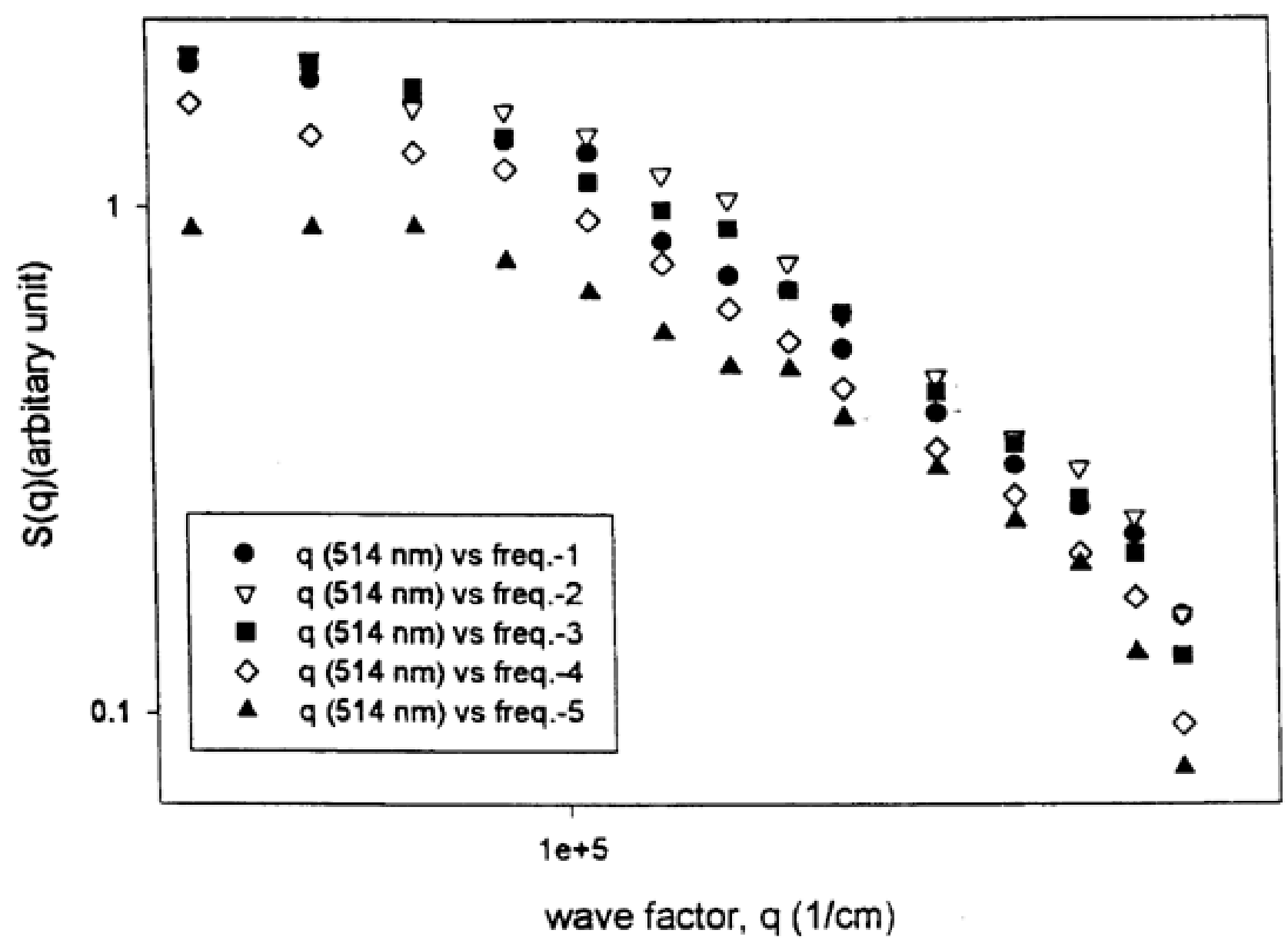


Figure 3. Measured signal (S) vs. wave factor (q)

Signal Inversion: wave length $=488 \mathrm{~nm}$

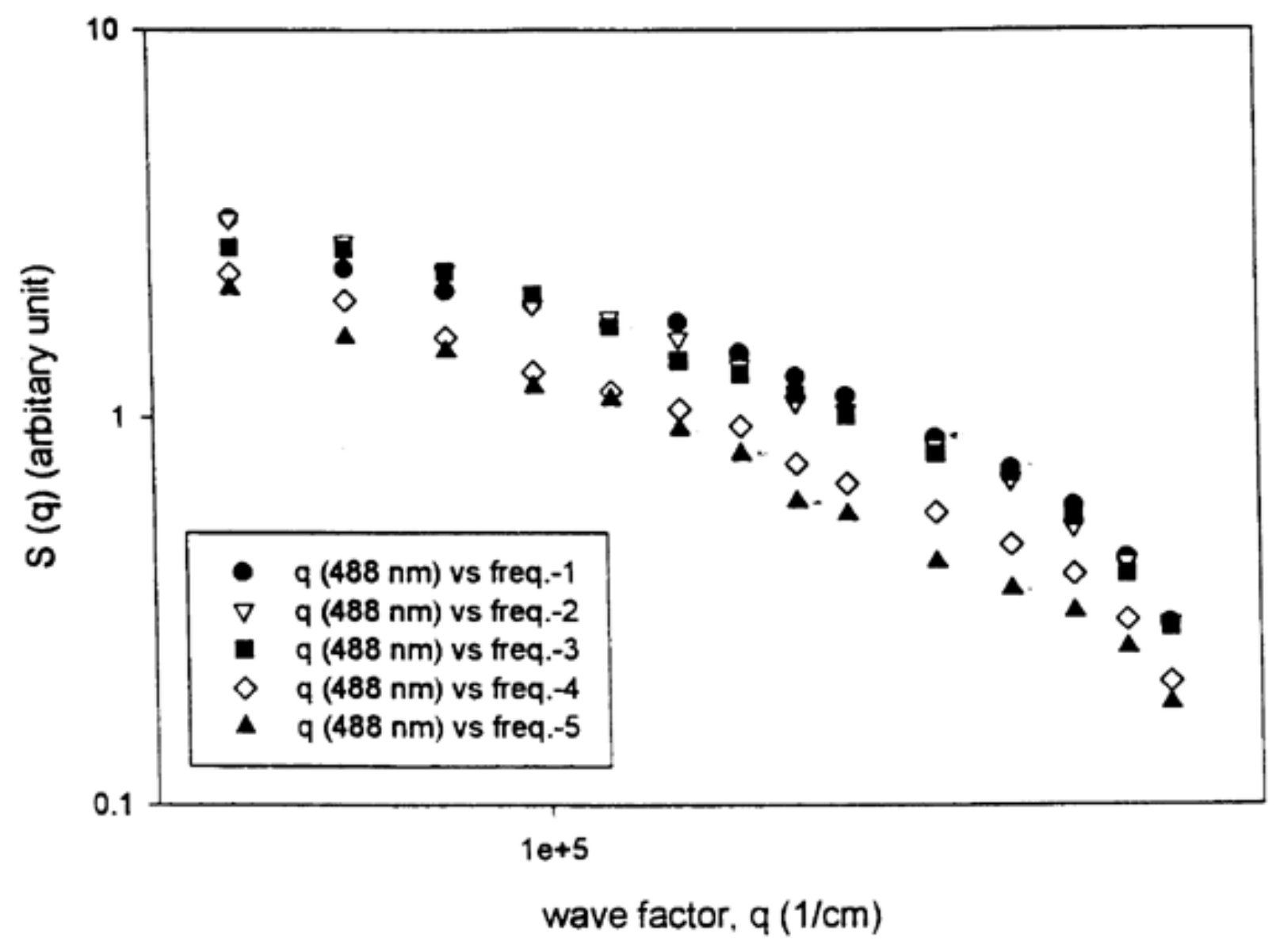




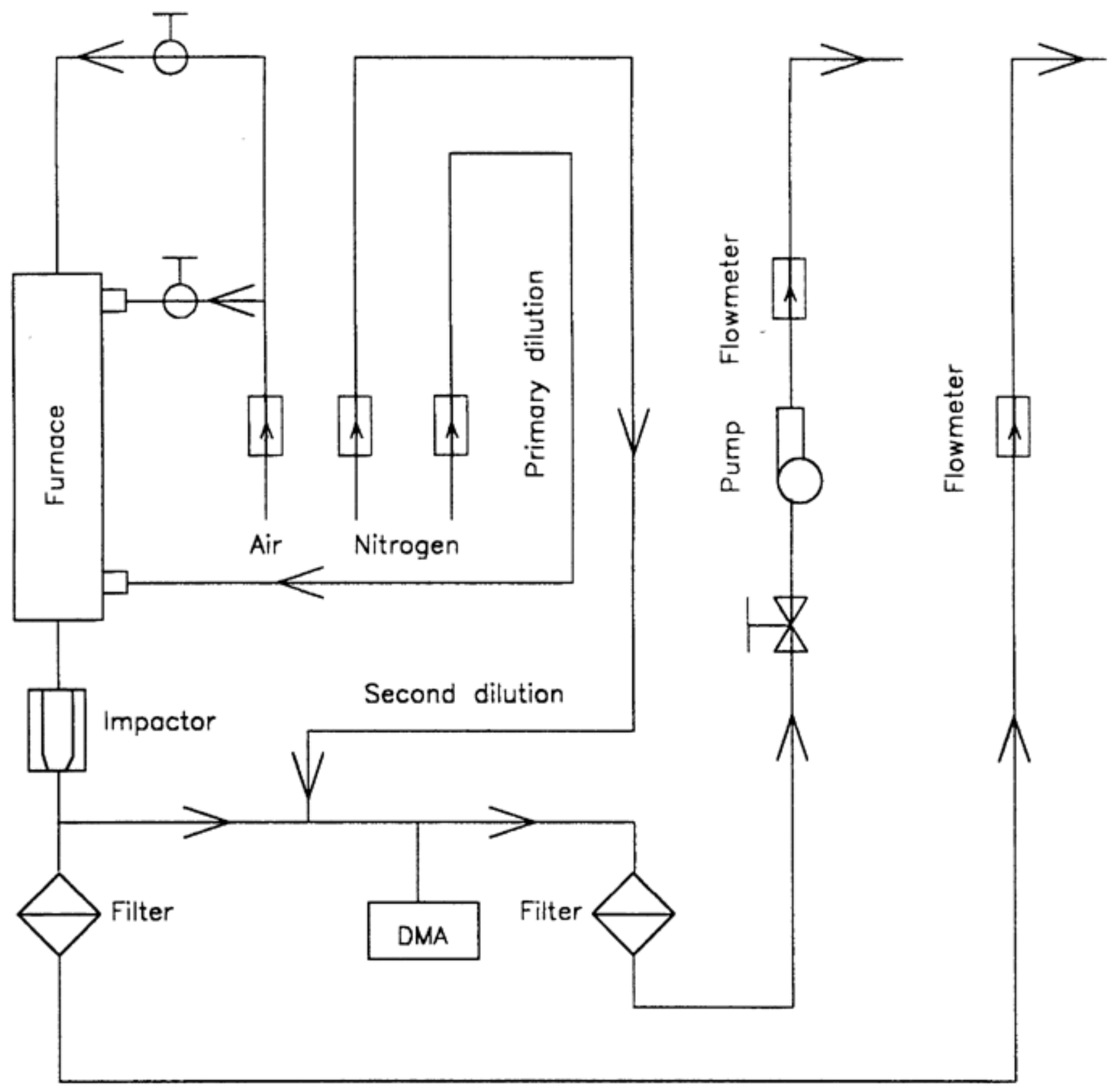

Fig.4 Schematic Diagram of the Cool Combustor 


\section{Fig.5 The Variation of Total Number Conc. of Sub-micronmeter Particle $\left(\mathrm{dp}_{50}<0.53 \mu \mathrm{m}\right)$ with Time}

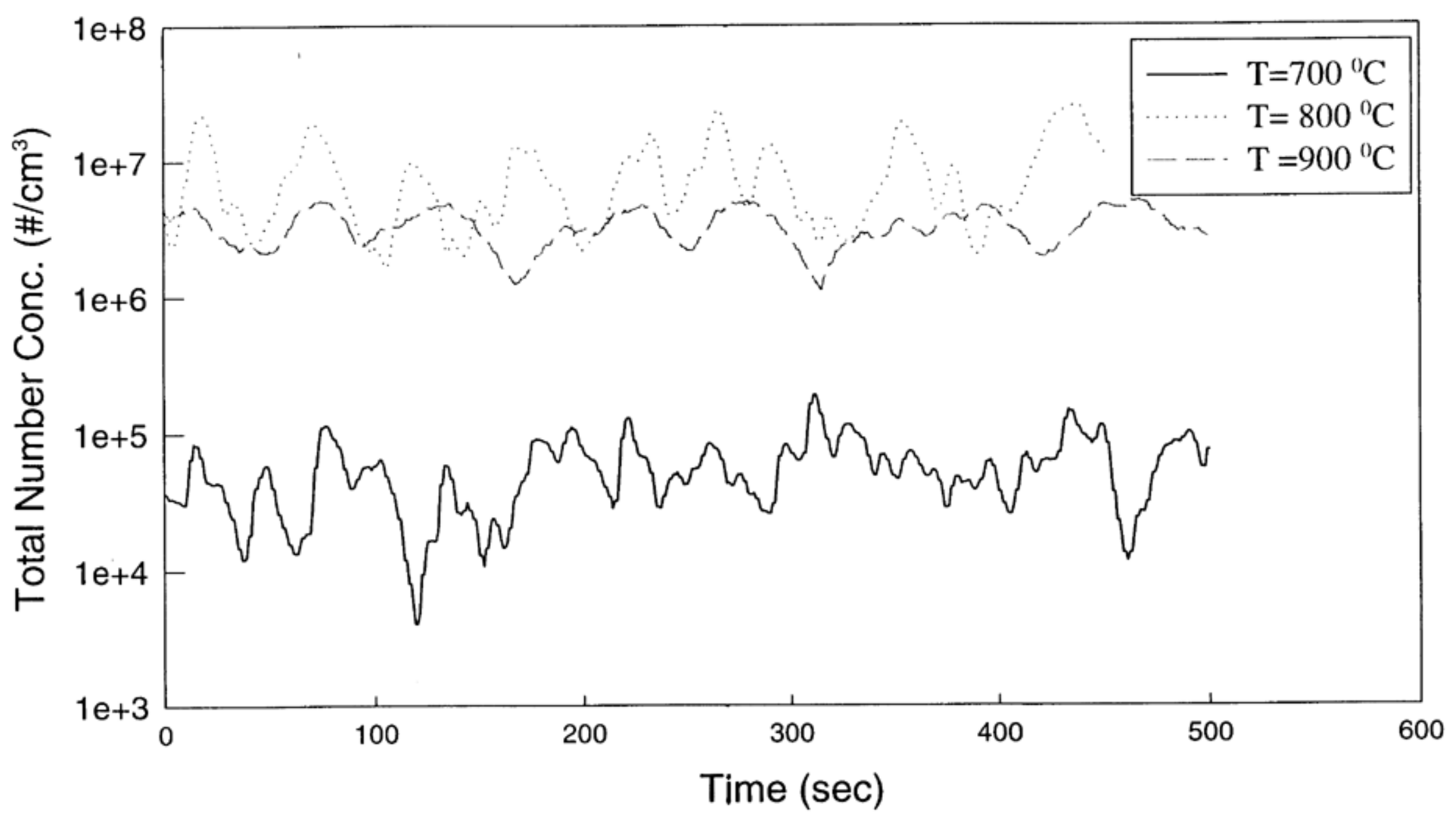


Fig.6 Effect of flow rate of air on total number concentration

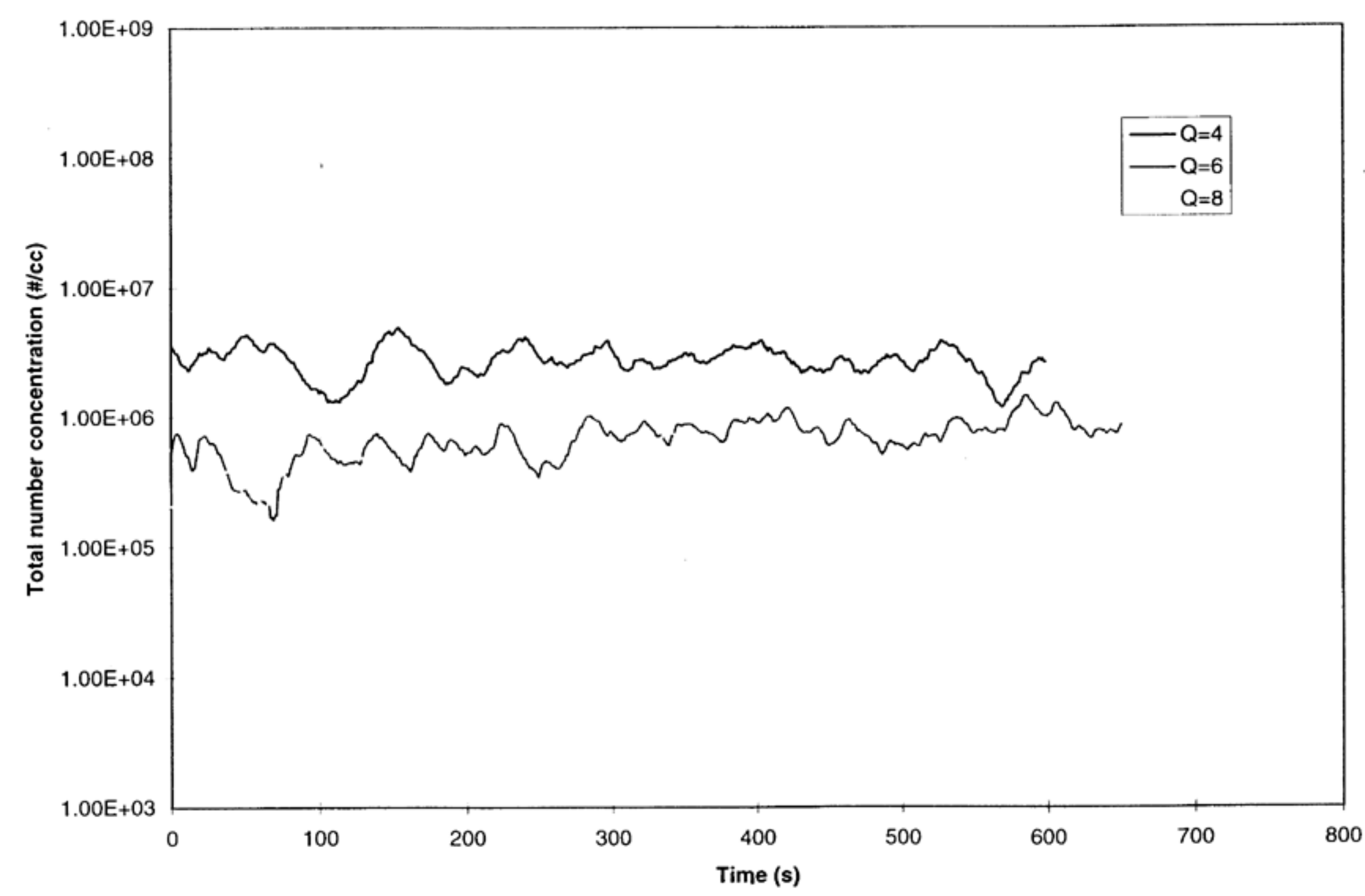


Fig.7 Effect of temperature on particle size distribution

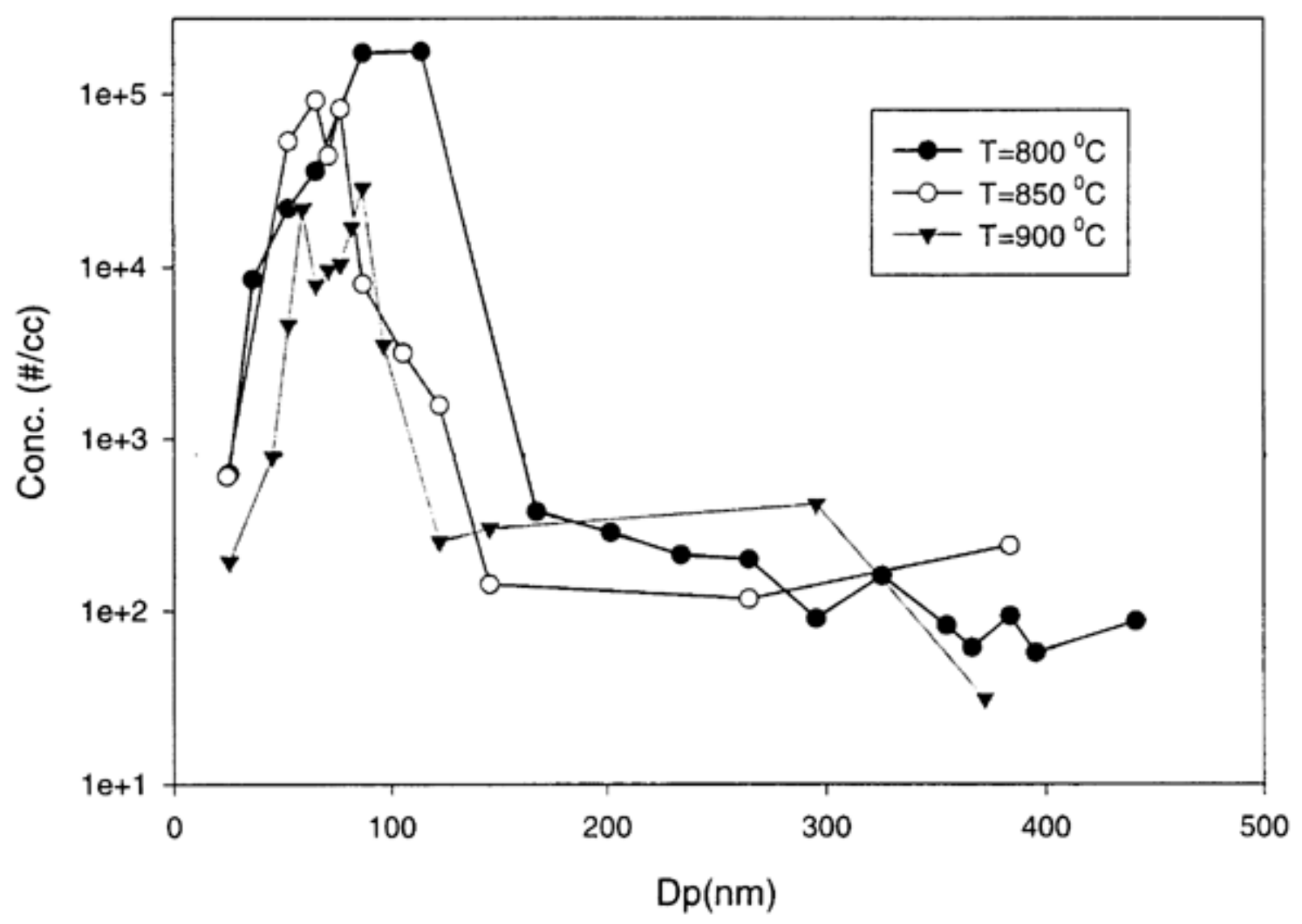

